Наведені результати теоретичних та експериментальних досліджень впливу шорсткості поверхонь на трібологічні властивості контакту «колесо-рейка» в криволінійних ділянках колії метрополітену. За результатами досліджень встановлені значення раціональної шорсткості контактуючих поверхонь, що послугує передумовою створення технологї превентивного иліфування рейок для уповільнення їх зносу при русі в криволінійних ділянках колії метрополітену

Ключові слова: контактні напруження, модельні зразки, раціональна шорсткість, «колесо-рейка», колія метрополітену

Даны результаты теоретических и экспериментальных исследований влияния шероховатости поверхностей на трибологические свойства контакта «колесорельс» в криволинейных участках пути метрополитена. По результатам исследований установлены значения рациональной шероховатости контактирующих поверхностей, что послужит предпосылкой создания технологии превентивного илифования рельсов для замедления их износа при движении в криволинейных участках пути метрополитена

Ключевые слова: контактные напряжения, модельные образцы, рациональная шероховатость, «колесо-рельс», путь метрополитена

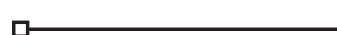

The velocity and safety of transportation process at railway transport depend on stability and durability of the contact components «wheel-rail» that can be guaranteed only by maintaining these components of railway infrastructure in constant «operable» condition [1].

The operating, constructional and tribological techniques are used to prolong the life cycle of railway wheels and rails. To solve the problem of extremely heavy wear in the contact «wheel-rail» in curvilinear sections of underground railway tracks we have to use the tribological techniques. They can be used to explore the regularities of contacting of forces which operate in contact and values of rational parameters of microgeometry of contacting surfaces that in turn will allow predicting the wear rate of surfaces under various contact conditions.

The wear rate depends on mechanical and tribological factors, which in contacting in curvilinear sections of a track lead to extremely heavy wear. It is impossible to eliminate the wear of contacting surfaces entirely as an unconditional

\section{DETERMINATION OF RATIONAL ROUGHNES OF THE SIDE SURFACE OF THE RAIL TOP IN CURVED SECTIONS OF THE UNDERGROUND RAILWAY TRACK}

\author{
S. Voronin \\ Doctor of Science in Technology, associate professor* \\ E-mail: voronin.sergey@inbox.ru \\ 0. S k or y k \\ Candidate of Technical Sciences, associate professor \\ Department of Track and track fasilites** \\ E-mail: dek_srt@ukr.net \\ Ye. Korostelov \\ PhD student* \\ E-mail: kostya_90@mail.ru \\ *Department of Construction, track \\ and handling machines** \\ **Ukrainian State University \\ of Railway Transport \\ Feuerbach sq., 7, Kharkov, Ukraine, 61050
}

result of their interaction and that is why one can only reduce it to some minimum value.

Among the promising techniques used to reduce friction and wear in metal sliding pairs there is application of lubricants and providing surface layers of metal with relevant mechanical properties and microgeometry. To implement these techniques it is necessary to study the influence of each factor (lubricating film, material impact, and surface microgeometry). At the second stage, one has to explore the composite impact of these factors on wear resistance of rails and wheels of rolling stock.

\section{Literature review and problem statement}

In order to reduce the wear rate in the contact «wheelrail» in recent years the researches were conducted that aimed to create conditions in which wheels of rolling stock and rails will wear out as slowly as possible. Basically, among the possible ways to achieve this, the change of the contact parameters was considered. In particular, it was noted that, despite the high cost of replacing worn-out wheels and 
rails, and the labor content of repair work, the solution of these problems is a priority [2-4]. For now, the problem of reducing the wear rate for the contact «wheel-rail» taking into account all features of contacting wasn't resolved. This problem is resolved in specific cases for a specific contact [5-7]. The majority of these researches were conducted taking into account only some contact characteristics with a large number of simplifications. Also, these researches are complicated by differences in the interaction of friction pairs «wheel-rail» taking into account operating, constructional and tribological peculiarities of contacting, and that is why require a complex solution for a specific type and conditions of contacting.

In [8] existing techniques of reducing side wear of rails in friction pair «wheel-rail» were analyzed and tribological techniques of reducing extremely heavy wear of the side surface of rails as the most effective for contacting conditions of system «wheel-rail» in curvilinear sections of the underground railway track were considered. For this purpose, it is necessary to explore the impact of microgeometry of contacting surfaces on friction coefficient and wear rate.

The influence of the rate of motion and roughness of contacting surfaces on the voltage value in the contact «wheelrail» was defined for conditions of main-line railways in the works $[9,10]$. For contacting in underground railway tracks especially in curvilinear sections of a track, the problem connected with definition of the dependence of the friction coefficient on microgeometry parameters of contacting surfaces is still insufficiently explored, taking into account the specifics of the friction pair.

In [11] values of force stresses in the contact «wheel-rail» for contacting conditions in underground railway tracks in straight-line sections of a track were defined. For contacting conditions in curvilinear sections, it is necessary to take into account the action of side forces and also material characteristics.

To create rational microgeometry parameters of contact in [12] it was offered to grind rails. When grinding it is necessary to take into account peculiarities of contacting conditions and material of contact bodies that is possible for conditions of the underground railway, taking into consideration uniformity of rolling stock and elements of the upper structure of the underground railway track on lines.

The grinding of wheels $[13,14]$ of rails in the process of operation on the railway track is used to extend their lifetime for a long time [15]. This type of work is mainly aimed at profiling of the rail top and is not intended for creating certain parameters of surface microgeometry. Considering this fact, it is necessary to define the processing technique of wheels and rails when grinding by selecting the appropriate abrasive material that creates a rational roughness.

In order to increase the friction coefficient in the contact «wheel-rail» and accelerate the wearing-in of contacting surfaces for conditions of pit-run railway transport in [12] the value of rational roughness was defined. However, these researches were conducted in order to increase the friction coefficient by giving contacting surfaces certain roughness under the condition of contacting in difficult conditions of heavy-weight pit-run railway transport to increase adhesion coefficient in contact. Therefore, it is impossible to use them to determine rational, from the standpoint of minimum, friction coefficient in contact «wheel-rail» in curvilinear sections of the underground railway track.
That is why the researches, considering the major forces which operate in contact «wheel-rail» in curvilinear sections of the underground railway track, seem to be promising, particularly taking into account operations of side forces, conditions of contacting and material properties of real contact bodies. Previously in [16] the contact «wheel-rail» on the side surface of a track using friction machine was modeled. This work is a continuation and practical implementation of the works $[8,16]$.

\section{Goals and research tasks}

The researches were conducted to determine the impact of parameters of roughness of contacting surfaces of wheel and rail in curvilinear sections of the underground railway track on the processes of their friction and wear.

To achieve this goal, the following problems were solved:

- the values of maximum contact stresses, which operate in curvilinear sections of the underground railway track taking into account action of side forces were defined;

- the values of forces, which operate in the real contact «wheel-rail» in curvilinear sections of the underground railway track to create force, which was applied to the «model contact» on a friction machine were defined;

- the parameters of rational roughness of the side surface of the rail top in curvilinear sections of the underground railway track by criteria of minimum friction and wear rate in contact were found.

\section{Determination of rational parameters of microgeometry of contacting surfaces \\ in the tribo-contact «wheel-rail» in curvilinear sections of the underground railway track}

4. 1. Theoretical researches of determination of rational parameters of microgeometry of contacting surfaces in the contact «wheel-rail» in curvilinear sections of the underground railway track

It was established that if friction is without lubrication, friction force decreases as the roughness rate of contacting surfaces increases [17]. In a considerable interval of changes in the degree of roughness, friction force remains constant, and if the surface was very roughly worked it is possible to observe a low increase in friction force (Fig. 1).

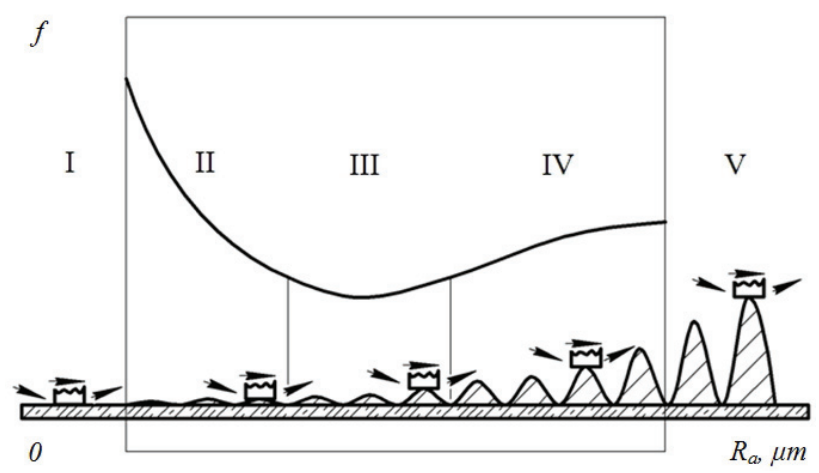

Fig. 1. Dependence of friction force on the roughness of unlubricated contacting surfaces: I - adhesion zone; II - zone of prevalent molecular wear; III - optimal zone of molecular-kinetic wear; IV - zone of prevalent mechanical wear; V - zone of microcutting 
The law of variation in friction coefficient with roughness is different for friction of rest and friction of motion [17]. When sliding, the friction coefficient depending on roughness passes through a minimum. The increase in friction force with an increase in roughness for sliding friction force is explained by energy dissipation, which occurs when sliding and increases with increase of roughness. The increase occurs faster than the decrease of the friction force component caused by the decrease of the contact area.

Considering molecular-mechanical nature of friction [18] it was established that the dependence between the friction coefficient and the rate of roughness has to be represented by a U-shaped curve. At sufficiently clean surfaces, the pair metal-metal forms nodes of adhesion owing to close contact. The change in friction coefficient in this area is represented by dropping curve piece. Further increase in roughness rate leads to the fact that the process of adhesion does not develop and interaction of surfaces in this area occurs owing to mechanical hooking of microroughnesses. The higher the friction coefficient in this interval of values of roughness parameters, the higher the rate of roughness. The value of rational roughness equals to minimum friction coefficient and minimum value of wear of materials (Fig. 2).

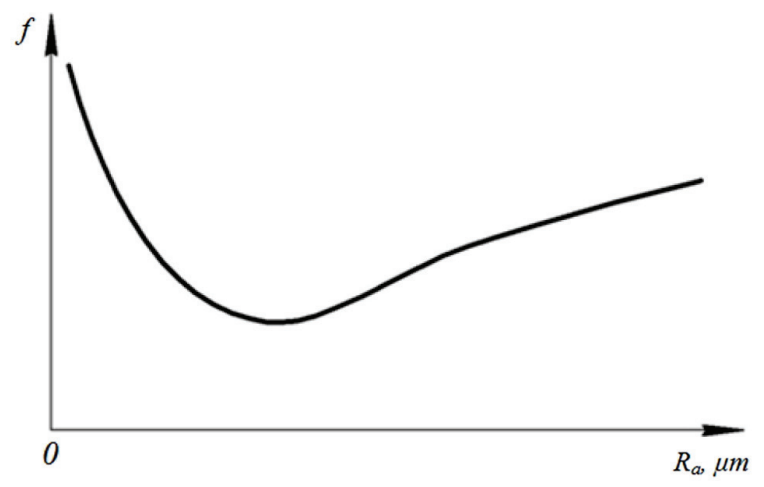

Fig. 2. Dependence of friction coefficient on roughness of contacting surfaces

The wheel rolling along the rail is the rolling of one cylindrical surface with radius $r_{1}$ along another one with radius $\mathrm{r}_{2}[19]$.

According to the theory [20] with additions [21], in [11] maximum contact voltages in the contact «wheel-rail» in direct sections of the underground railway track were defined. As in curvilinear sections of a track contact spot has non-elliptic contact, so the value of maximum contact voltages should be determined by the technique [22]. According to this technique the value of maximum contact voltages in curvilinear sections of a track should be defined taking into account correction coefficients for analogous values defined using the technique [20] with additions [21] in [11] in direct section of a track. The total value of correction coefficients can be $2 \div 2.5$.

The maximum contact voltages in the contact «wheelrail» under conditions of underground railway were calculated earlier in [11], but without taking into account actions of side forces in curvilinear sections of a track, which significantly affect the value of contact voltages. That is why in this work actions of side forces were taken into account (Fig. 3):

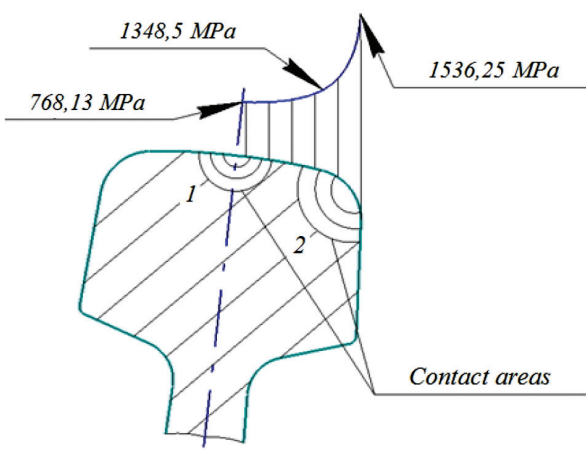

Fig. 3. Maximum contact voltages in accordance with [20-23]: 1 - contact on the surface of rolling rail (contacting is predominantly in direct sections of a track); 2 - contact on the side surface of the rail top (contacting is predominantly in curvilinear sections of a track)

The wear rate of contacting surfaces depends on the type of their contact interaction. That is why to have higher wear resistance it is necessary to provide elastic interaction of contacting bodies.

The wear rate I can change within the range from $10^{-3}$ to $10^{-12} \mathrm{~cm}^{3} / \mathrm{cm}$ [14]. Considering the contact «wheel-rail» as a multiple contact, there is a fundamental equation to calculate the wear rate of the given contact [24]:

$$
\mathrm{I}=\mathrm{K}_{1} \cdot \alpha \cdot \sqrt{\frac{\mathrm{h}}{\mathrm{r}}} \cdot \frac{\mathrm{p}_{\mathrm{a}}}{\mathrm{p}_{\mathrm{r}}} \cdot \frac{1}{\mathrm{n}}
$$

The approximate formula for defining the depth of immersion of irregularities $h$ under condition of the absence of undulation of contacting surfaces is:

$$
\mathrm{h} \approx 3.4 \cdot \mathrm{R}_{\mathrm{a}} \cdot \sqrt[3]{\left(\frac{\mathrm{p}_{\mathrm{c}}}{\mathrm{p}_{\mathrm{r}}}\right)}
$$

Thus the real contact pressure is calculated using the formula:

$$
\mathrm{p}_{\mathrm{r}}=0.5 \cdot \mathrm{E}^{\frac{2 \mathrm{v}}{2 \mathrm{v}+1}} \cdot \Delta^{\frac{\mathrm{v}}{2 \mathrm{v}+1}} \cdot \mathrm{p}_{\mathrm{c}^{\frac{1}{2 \mathrm{v}+1}}}
$$

Contour pressure (without impact of roughness on wave deformation) is

$$
\mathrm{p}_{\mathrm{c}}=0.2 \cdot \mathrm{E}^{0.8} \cdot\left(\frac{\mathrm{H}_{\mathrm{B}}}{\mathrm{R}_{\mathrm{B}}}\right)^{0.4} \cdot \mathrm{p}_{\mathrm{a}}{ }^{0.2} .
$$

After the wear rate in the contact «wheel-rail» in curvilinear sections of a track is calculated, it will be possible to select rational contacting parameters of the given system.

4.2. Bench tests to determine rational parameters of microgeometry of contacting surfaces in the contact «wheel-rail» in curvilinear sections of the underground railway track

We use the above values of contact voltages to model the contact «wheel-rail» at a laboratory bench.

In order to simulate in laboratory conditions the contact «wheel-rail» in the curvilinear section of a track, it is necessary to recalculate parameters of the modeling sample in such a way that maximum contact voltages in the «modeling» 
contact corresponded to maximum contact voltages in the real contact.

To define rational roughness of contacting surfaces in laboratory conditions, it is also necessary to generate parameters of surface roughness that means to select the granularity of abrasive material, by which they will be worked.

Before performing laboratory tests, the following ranges of changes in parameters of surface roughness were selected: $R_{a}=1 \ldots 4 \mathrm{mcm}$. According to these values, abrasive paper P150, P220, P320, P500 was selected. Before performing the following series of tests, produced modeling samples were worked by selected for each series of tests abrasive paper to obtain contacting surfaces with the roughness $R_{a}=1,2,3,4 \mathrm{mcm}$, and also at different loads $\mathrm{P}=7,10,13 \mathrm{kgf}$. Materials for producing modeling samples of contacting bodies were selected in accordance with materials of wheel and rail.

According to tribology works [24,25], it is known that it is possible to predict the wear rate of friction components indirectly by means of experimental determination of friction force in contact. This conventional approach allows reducing labor intensiveness of researches and at the same time improving the accuracy and informativity of measurement results.

To measure maximum force and friction coefficient in contact, a laboratory bench was used (Fig. 4).

This bench makes possible to simulate contact «wheelrail» using circuit «disk-plane». The disk has a spherical surface of rolling that helps to reproduce the process of wheel rolling on the rail under conditions of single-point contact.

The experimental technique provides application of vertical force $\mathrm{P}$ to the roller, which in terms of dimension ratio of the real contact «wheel-rail» in the curvilinear section of the underground railway track meets the same specifications for laboratory models. Using the connecting shaft, constant

twisting moment $\mathrm{M}$ is supplied from the electric motor to the roller. Under the motion platform, a linear potentiometer was attached to the bed plate. The runner of the potentiometer is connected to the object table and moves with it. The potentiometer is connected to a digital transducer, which can be connected to a computer via USB-input. The digital transducer, springs and linear potentiometer together represent a digital dynamometer. During the experiment, the signal from the digital dynamometer is displayed on a computer screen in the form of a graph, which describes the dependence of the roller friction force on the table movement.

According to each series of measurements, the average friction force is calculated and then the average friction coefficient for each series of tests is calculated (Table 1).

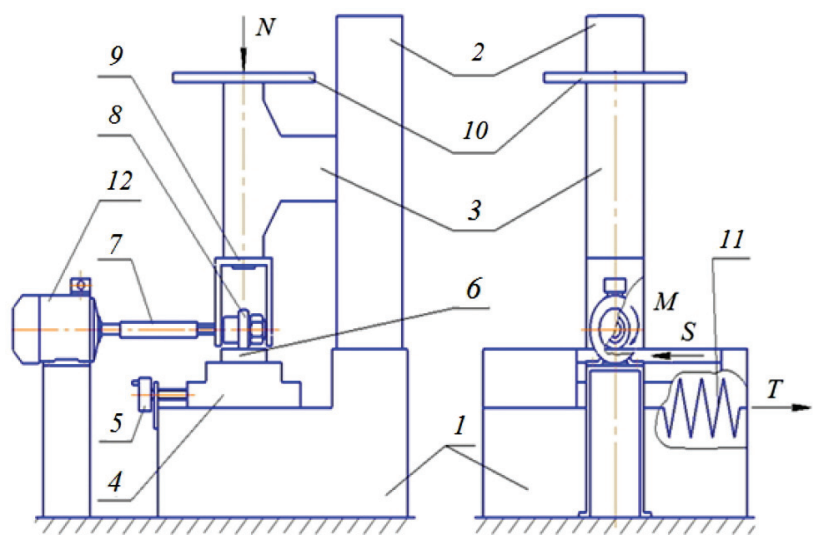

Fig. 4. Circuit of laboratory bench: 1 - bed plate; 2 - guidepost; 3 - supporting arm; 4 - motion platform; 5 - flywheel of crossfeed; 6 - rail sample (plate); 7 - connecting shaft; 8 - wheel sample (roller); 9 - roller frame; 10 - point of load application; 11 - spring; 12 - electric motor

Table 1

Research results on the friction machine under conditions of unlubricated contact

\begin{tabular}{|c|c|c|c|c|c|c|c|c|c|c|c|}
\hline \multirow{2}{*}{$\begin{array}{c}\text { Roughness of contacting } \\
\text { surfaces }\end{array}$} & \multicolumn{10}{|c|}{ Friction coefficient $\mathrm{f}$} & \multirow{2}{*}{$\mathrm{f}$} \\
\hline & 1 & 2 & 3 & 4 & 5 & 6 & 7 & 8 & 9 & 10 & \\
\hline \multicolumn{12}{|c|}{ When $\mathrm{P}=7 \mathrm{kgf}$} \\
\hline $\mathrm{R}_{\mathrm{a}}=1 \mathrm{mcm}$ & 0.252 & 0.255 & 0.254 & 0.253 & 0.256 & 0.257 & 0.258 & 0.260 & 0.259 & 0.261 & 0.255 \\
\hline $\mathrm{R}_{\mathrm{a}}=2 \mathrm{mcm}$ & 0.233 & 0.234 & 0.233 & 0.234 & 0.235 & 0.237 & 0.237 & 0.239 & 0.241 & 0.240 & 0.235 \\
\hline $\mathrm{R}_{\mathrm{a}}=3 \mathrm{mcm}$ & 0.237 & 0.239 & 0.240 & 0.238 & 0.239 & 0.237 & 0.239 & 0.242 & 0.241 & 0.240 & 0.239 \\
\hline $\mathrm{R}_{\mathrm{a}}=4 \mathrm{mcm}$ & 0.242 & 0.244 & 0.241 & 0.244 & 0.246 & 0.248 & 0.246 & 0.247 & 0.244 & 0.248 & 0.245 \\
\hline \multicolumn{12}{|c|}{ When $P=10 \mathrm{kgf}$} \\
\hline $\mathrm{R}_{\mathrm{a}}=1 \mathrm{mcm}$ & 0.259 & 0.262 & 0.260 & 0.262 & 0.262 & 0.258 & 0.262 & 0.266 & 0.263 & 0.264 & 0.262 \\
\hline $\mathrm{R}_{\mathrm{a}}=2 \mathrm{mcm}$ & 0.235 & 0.238 & 0.234 & 0.237 & 0.239 & 0.240 & 0.241 & 0.237 & 0.236 & 0.237 & 0.237 \\
\hline $\mathrm{R}_{\mathrm{a}}=3 \mathrm{mcm}$ & 0.237 & 0.241 & 0.237 & 0.239 & 0.243 & 0.239 & 0.242 & 0.242 & 0.243 & 0.243 & 0.241 \\
\hline $\mathrm{R}_{\mathrm{a}}=4 \mathrm{mcm}$ & 0.245 & 0.249 & 0.241 & 0.246 & 0.244 & 0.249 & 0.246 & 0.248 & 0.251 & 0.253 & 0.247 \\
\hline \multicolumn{12}{|c|}{ When $\mathrm{P}=13 \mathrm{kgf}$} \\
\hline $\mathrm{R}_{\mathrm{a}}=1 \mathrm{mcm}$ & 0.261 & 0.260 & 0.263 & 0.265 & 0.267 & 0.264 & 0.265 & 0.268 & 0.267 & 0.264 & 0.265 \\
\hline $\mathrm{R}_{\mathrm{a}}=2 \mathrm{mcm}$ & 0.238 & 0.239 & 0.242 & 0.243 & 0.241 & 0.245 & 0.242 & 0.243 & 0.239 & 0.240 & 0.241 \\
\hline $\mathrm{R}_{\mathrm{a}}=3 \mathrm{mcm}$ & 0.245 & 0.245 & 0.247 & 0.244 & 0.244 & 0.243 & 0.243 & 0.246 & 0.243 & 0.246 & 0.245 \\
\hline $\mathrm{R}_{\mathrm{a}}=4 \mathrm{mcm}$ & 0.249 & 0.250 & 0.253 & 0.254 & 0.251 & 0.250 & 0.251 & 0.253 & 0.249 & 0.254 & 0.252 \\
\hline
\end{tabular}


The values of the average friction coefficient for all the examined range of roughness of contacting surfaces are shown in Fig. 5.
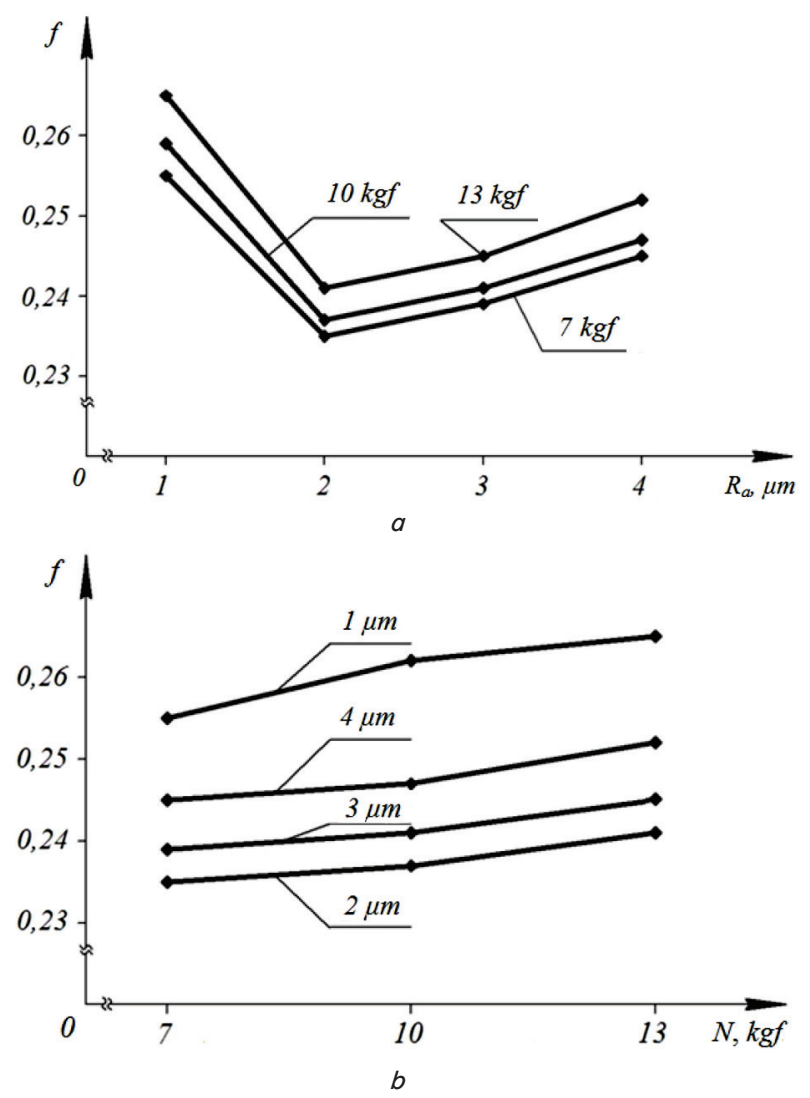

Fig. 5. Graphical display of test results under conditions of unlubricated friction: $a-$ dependence of friction coefficient on the roughness of contacting surfaces; $b$ - dependence of friction coefficient on vertical load at a given roughness of contacting surfaces

Using the obtained values of the microgeometry of contacting surfaces in the friction pair «wheel-rail», we define the value the wear rate in the «modeling» contact according to test results at a laboratory bench (Fig. 6).

Shown in Fig. 6 point-by-point diagrams reflect the values of wear rate of the side surface of the rail top of underground railway depending on the roughness of contacting surfaces.

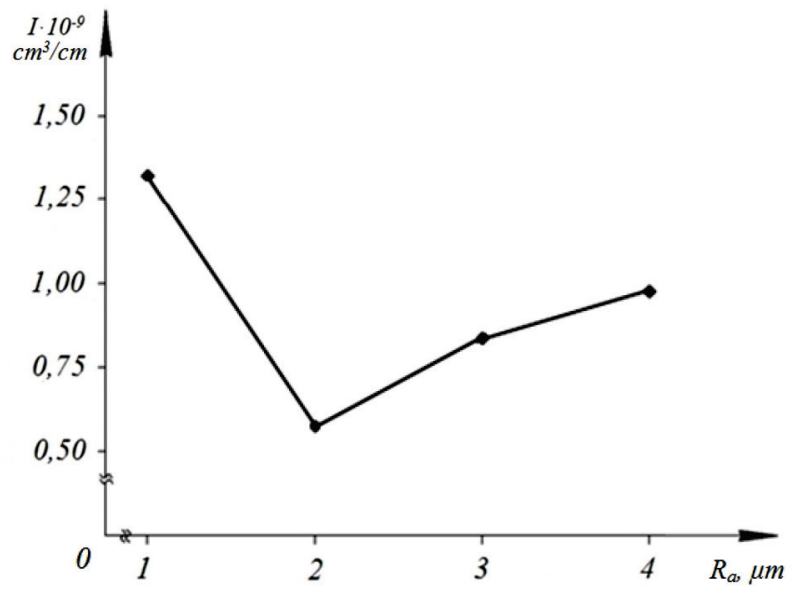

Fig. 6. The values of wear rate in the «modeling» contact «wheel-rail» according to test results at a laboratory bench

\section{Research results on definition of rational roughness of contacting surfaces in the contact «wheel-rail» in curvilinear sections of the underground railway and their discussion}

The analysis of previous researches in the sphere of contacting interaction of the tribosystem «wheel-rail» gave an opportunity to apply the methodological approach when performing research of the impact of roughness of contacting surfaces on tribological characteristics of the contact «wheel-rail» in curvilinear sections of the underground railway track. According to this approach, when carrying out laboratory «modeling» tests it is appropriate to calculate the sliding friction force and using the obtained data to calculate the friction coefficient and wear rate.

The laboratory researches have proved that roughness of contacting surfaces significantly affects the friction force in the «modeling» contact and there is a region of minimum friction when the roughness value equals $2 \mathrm{mcm}$. Using this value of microgeometry parameters of contacting surfaces, the wear rate is $\mathrm{I}=0.53 \cdot 10^{-9} \mathrm{~cm}^{3} / \mathrm{cm}$.

The obtained results of laboratory researches were applied when performing operating tests of the rails of the underground railway in order to design a process of preventative rail-grinding in curvilinear sections of the underground railway track that will provide minimum costs of friction and wear.

To extend the lifetime of rails, which are operated in underground railway tracks it is necessary to create such conditions of their mutual contacting that could give an opportunity to operate in longest possible terms without prejudicing the security and uninterrupted processes of passengers' transportation [1]. For this purpose, it is necessary to monitor the wear of contacting surfaces and, if it is required, to carry out a proper action to reduce the wear rate of rails in curvilinear sections of the underground railway track, because under these conditions rails are subjected to heavy wear. Using tribological techniques, it is possible to significantly slow down the process of defect formation of rails [8].

The results obtained after performing laboratory tests confirmed that there is a well-defined dependence between the roughness of contacting surfaces and the friction coefficient and as a result it affects the wear rate in the tribocontact «wheel-rail». The opinion of scientists that the dependence between the friction coefficient and roughness degree has the form of the U-shaped curve with inflection in the point of minimum value of the friction coefficient, which corresponds to exactly rational in terms of contact tribology roughness value is also confirmed.

Using the obtained under laboratory conditions values of rational microgeometry parameters of the contact «wheelrail» under conditions of contacting in the curvilinear section of the underground railway track, it is possible to develop the technology of preventative rail-grinding of tracks Utility Enterprise «Kharkov Metro» (Ukraine) to predict extreme wear. However, the results obtained under laboratory conditions must be compared with the corresponding values, which will be obtained after «field» tests on underground railway tracks. This work is a continuation and practical implementation of the works $[8,16]$. Researchers on definition of rational parameters of microgeometry of contacting surfaces of wheels and rails will be conducted under conditions of underground railway to specify and compare the results obtained under laboratory conditions. As a result, it will give an opportunity to obtain rational parameters of roughness of contacting surfaces in contact «wheel-rail» and to develop 
the technology of preventative rail-grinding at the Utility Enterprise «Kharkov Metro» (Ukraine).

\section{Conclusions}

After analyzing the research in the field of contact interaction of the tribosystem «wheel-rail» to reduce wear of contacting surfaces, some problems were solved in this work:

1. The values of contact voltages $\sigma=1536.25 \mathrm{MPa}$, which act in curvilinear sections of the underground railway track considering side forces were defined.
2. The range of force values $\mathrm{P}=7,10,13 \mathrm{kgf}$, which must be applied to the «modeling» contact to represent at a laboratory bench the force impact on the contact «wheelrail» in curvilinear sections of the underground railway track was defined.

3. The parameters of rational roughness of the side surface of the rail top in curvilinear sections of the underground railway track that is $R_{a}=2 \mathrm{mcm}$ were defined. If contacting surfaces of the wheel and the rail are worked in accordance with the given coefficient value friction will be minimum $\mathrm{f}=0.241$. The wear rate is $\mathrm{I}=$ $=0.53 \cdot 10^{-9} \mathrm{~cm}^{3} / \mathrm{cm}$.

\section{References}

1. Shtompel, A. Problema rivnoresursnosti elementiv verkhnoyi budovy bezstykovoyi koliyi [Text] / A. Shtompel, O. Skoryk, O. Ovchynnikov // Sbornyk nauchnykh trudov SWorld. - 2014. - Vol. 3, Issue 36. - P. 64-69.

2. Wang, W. J. Wear and damage transitions of wheel and rail materials under various contact conditions [Text] / W. J. Wang, R. Lewis, B. Yang, L. Guo, Q. Liu, M. Zhu // Original Research Article Wear. - 2016. - Vol. 362-363. - P. 146-152. doi: 10.1016/ j.wear.2016.05.021

3. Santamaria, J. Wheel-rail wear index prediction considering multiple contact patches [Text] / J. Santamaría, E. G. Vadillo, O. Oyarzabal // Original Research Article Wear. - 2009. - Vol. 267, Issue 5-8. - P. 1100-1104. doi: 10.1016/j.wear.2008.12.040

4. Ignesti, M. Development of a wear model for the prediction of wheel and rail profile evolution in railway systems [Text] / M. Ignesti, M. Malvezzi, L. Marini, E. Meli, A. Rindi // Original Research Article Wear. - 2012. - Vol. 284-285. - P. 1-17. doi: 10.1016/ j.wear.2012.01.020

5. Alonso, A. Wheel-rail contact: Roughness, heat generation and conforming contact influence [Text] / A. Alonso, J. G. Gimenez // Tribology International. - 2008. - Vol. 41, Issue 8. - P. 755-768. doi: 10.1016/j.triboint.2008.01.004

6. Remington, P. Estimation of wheel/rail interaction forces in the contact area due to roughness [Text] / P. Remington, J. Webb // Journal of sound and vibration. - 1996. - Vol. 193, Issue 1. - P. 83-102. doi: 10.1006/jsvi.1996.0249

7. Rovira, A. Experimental and numerical modelling of wheel-rail contact and wear [Text] / A. Rovira, A. Roda, M. B. Marshall, H. Brunskill, R. Lewis // Original Research Article Wear. - 2011. - Vol. 271, Issue 5-6. - P. 911-924. doi: 10.1016/ j.wear.2011.03.024

8. Voronyn, S. Analyz sushchestvuyushchykh sposobov umenshenyya bokovoho yznosa relsov v pare trenyya «koleso-rels» v kryvukh uchastkakh puty [Text] / S. Voronyn, E. Korostelev // Informatsiyno-keruyuchi systemy na zaliznychnomu transporti. - 2014. Vol. 3. - P. 22-27.

9. Chen, H. Influence of axle load on wheel/rail adhesion under wet conditions in consideration of running speed and surface roughness [Text] / H. Chen, A. Namura, M. Ishida, T. Nakahara // Original Research Article Wear. - 2016. doi: 10.1016/j.wear.2016.05.012

10. Aharkov, O. Vyznachennya kontaktnykh napruzhen v reykakh typu P50, yaki ekspluatuyutsya v metropoliteni [Text] / O. Aharkov, R. Yosyfovych // Nauka ta prohres transportu. Visnyk Dnipropetrovs'koho natsional'noho universytetu zaliznychnoho transport. 2015. - Vol. 4, Issue 58. - P. 71-86.

11. Keropyan, A. Impact of Roughness of Interacting Surfaces of the Wheel-Rail Pair on the Coefficient Of Friction in Their Contact Area [Text] / A. Keropyan, S. Gorbatyuk // Procedia Engineering. - 2016. - Vol. 150. - P. 406-410. doi: 10.1016/j.proeng.2016.06.753

12. Yvanov, Y. A. Otsenka vozmozhnostey protsessov vosstanovlenyya profylya poverkhnosty kolesnykh par [Text] / Y. A. Yvanov // Visnyk Skhidnoukrayinskoho natsionalnoho universytetu imeni V. Dalya. - 2010. - Vol. 10, Issue 152. - P. 72-78.

13. Budyukyn, A. M. Vybor rezhyma vreznoyu shlyfovanyya kolesnoy staly [Text] / A. M. Budyukyn // Konstruktsyonno-tekhnolohycheskoe obespechenye nadezhnosty koles relsovykh ekypazhey, 2009. - P. 89-93.

14. Potapov, D. Systema shlifuvannya reyok v koliyi reykoshlifuvalnym poyizdamy z aktyvnymy robochymy orhanamy na zaliznytsyakh Ukrayiny [Text] / D. Potapov, V. Vitolberh // Informatsiyno-keruyuchi systemy na zaliznychnomu transporti. 2006. - Vol. 5, 6. - P. 70-73.

15. Voronyn, S. Modelyrovanye kontakta «koleso-rels» po bokovoy poverkhnosty puty na mashyne trenya [Text] / S. Voronyn, S. Karpenko, E. Korostelov // Zbirnyk naukovykh prats UkrDAZT. - 2014. - Vol. 148. - P. 201-204.

16. Krahelskyy, Y. V. Osnovy raschetov na trenye y yznos [Text] / Y. V. Krahelskyy. - Moscow: Mashynostroenye, 1977. - 526 p.

17. Krahelskyy, Y. V. Trenye y yznos [Text] / Y. V. Krahelskyy. - Moscow: Mashynostroenye, 1968. - 480 p.

18. Danilenko, E. Zaliznychna koliya. Ulashtuvannya, proektuvannya y rozrakhunky, vzayemodiya z rukhomym skladom. Vol. 2 [Text] / E. Danilenko. - Kyiv: Inpres, 2010. - 457 p. 
19. Belyaev, N. M. Soprotyvlenye materyalov [Text] / N. M. Belyaev. - Moscow: Nauka, 1965. - 856 p.

20. Shakhunyants, H. Zheleznodorozhnuy put. 3rd edition [Text] / H. Shakhunyants. - Moscow: Transport, 1987. -479 p.

21. Albrekht, V. H. Osnovy ustroystva y raschetov zheleznodorozhnoho puty [Text] / V. H. Albrekht, M. P. Smyrnov, V. Ya. Shul'ha et. al.; S. V. Amelyn, T. H. Yakovleva (Eds.). - Moscow: Transport, 1990. - 367 p.

22. Yakovlev, V. Yssledovanye kontaktnykh napryazhenyy v elementakh kolesa y relsa pry deystvyy vertykalnykh y kasatelnykh syl [Text] / V. Yakovlev // Trudy LYYZHT. - 1967. - Vol. 187. - P. 3-89.

23. Krahelskyy, Y. Trenye yznashyvanye y smazka [Text] / Y. Krahelskyy, V. Alysyn. - Moscow: Mashynostroenye, 1978. - 400 p.

24. Sosnovskyy, L. Osnovy trybofatyky. Part 1 [Text] / L. Sosnovskyy. - Homel: BelHUT, 2003. - 246 p.

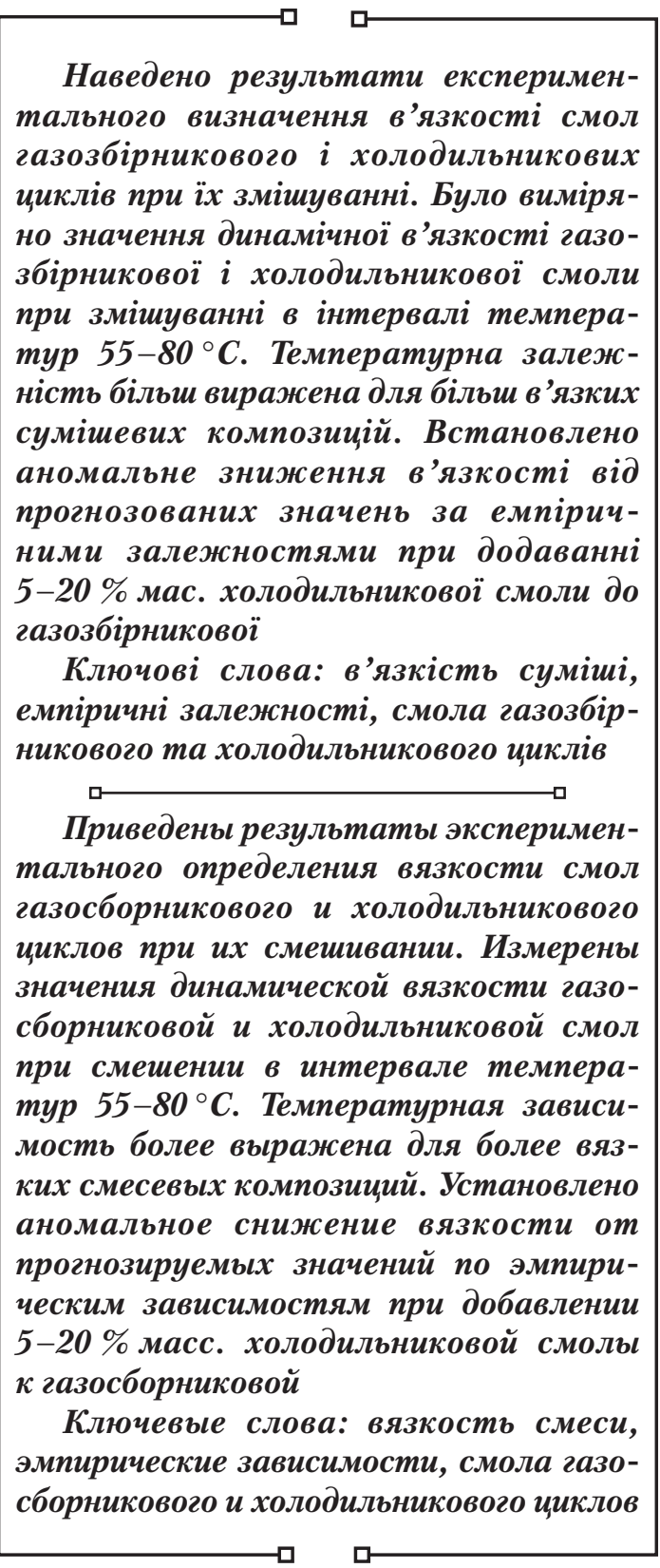

\section{Introduction}

Coal tar is the second largest product of coking plant after coke. The tar is unique and irreplaceable raw source of condensed aromatic compounds, oils and pitch [1]. Recovery of tar from the high temperature coking process takes place during the cooling and partial condensation of the volatile
UDC 66.09289 : 665.94

DOI: $10.15587 / 1729-4061.2016 .75736$

VISCOSITY EVALUATION OF THE MIXTURE OF COAL TARS FROM COLLECTION MAIN AND PRIMARY COOLER ON THE BASE OF RHEOMETER MEASUREMENTS AND EMPIRICAL FORMULAS

\author{
A. Pasternak \\ Chief Engineer \\ PJSC «Avdeevsky koksokhimichaskiy zavod» \\ Industrialniy driveway, 1, Avdiivka, Ukraine, 86065 \\ E-mail: root@akhz.com.ua \\ L. B a n n ikov \\ $\mathrm{PhD}$, Head of Department \\ Department of chemical* \\ E-mail: ukhinbannikov@gmail.com \\ A. S mirnova \\ Science engineer* \\ E-mail: pokhylko.anna.v@gmail.com \\ *Ukrainian State Research Institute of \\ Carbochemistry (UKHIN) \\ Vesnina str., 4, Kharkiv, Ukraine, 61023
}

products from coke oven. Condensation occurs twice while cooling gas processes: in the collecting main $\left(\approx 75-90{ }^{\circ} \mathrm{C}\right)$ and in the primary gas cooler (PGC) to $\approx 25-40{ }^{\circ} \mathrm{C}$.

As the result of two step condensation a heavy tar called «from collecting main» and a light tar called «from primary cooler» are produced in the condensation section of the chemical coking plant shop. Thus, in practice, all coal 